Research article

Open Access

\title{
1,1-dichloro-2,2-bis(p-chlorophenyl)ethylene (p,p'-DDE) disrupts the estrogen-androgen balance regulating the growth of hormone-dependent breast cancer cells
}

\author{
Michel Aubé1, Christian Larochelle ${ }^{1}$ and Pierre Ayotte ${ }^{1,2}$
}

\begin{abstract}
1 Unité de Recherche en Santé Publique, Centre de Recherche du Centre Hospitalier Universitaire de Québec-CHUL, 2875 boulevard Laurier, Québec, QC G1V 2M2, Canada

2Laboratoire des biomarqueurs, Institut national de santé publique du Québec, 945 avenue Wolfe, Québec, QC G1V 5B3, Canada

Corresponding author: Pierre Ayotte, pierre.ayotte@inspq.qc.ca

Received: 29 May 2007 Revisions requested: 11 Jul 2007 Revisions received: 10 Dec 2007 Accepted: 14 Feb 2008 Published: 14 Feb 2008

Breast Cancer Research 2008, 10:R16 (doi:10.1186/bcr1862)

This article is online at: http://breast-cancer-research.com/content/10/1/R16

(C) 2008 Aubé et al.; licensee BioMed Central Ltd.

This is an open access article distributed under the terms of the Creative Commons Attribution License (http://creativecommons.org/licenses/by/2.0), which permits unrestricted use, distribution, and reproduction in any medium, provided the original work is properly cited.
\end{abstract}

\begin{abstract}
Introduction Estrogen and androgen signalling pathways exert opposing influences on the proliferation of mammary epithelial and hormone-dependent breast cancer cells. We previously reported that plasma concentrations of 1,1-dichloro-2,2-bis $(p$ chlorophenyl)ethylene ( $\left.p, p^{\prime}-\mathrm{DDE}\right)$, the main metabolite of the insecticide DDT (1,1,1-trichloro-2,2-bis [ $p$-chlorophenyl]ethane) and a potent androgen antagonist, were associated with tumor aggressiveness in women diagnosed with breast cancer. We sought to examine the biological plausibility of this association by testing the effect of $p, p^{\prime}$-DDE on the proliferation of CAMA-1 cells, a human breast cancer cell line that expresses the estrogen receptor alpha (ER $\alpha$ ) and the androgen receptor (AR), in the presence of physiological concentrations of estrogens and androgens in the cell culture medium.
\end{abstract}

Methods The proliferation of CAMA- 1 cells was determined in 96-well plates following a 9-day treatment with $p, p^{\prime}$-DDE alone $(0.1$ to $10 \mu \mathrm{M})$ or in combination with $17 \beta$-estradiol $\left(E_{2}\right)(100$ $\mathrm{pM})$ and dihydrotestosterone (DHT) $(100,500$, or $1,000 \mathrm{pM})$. We also assessed $p, p^{\prime}$-DDE-induced modifications in cell cycle entry and the expression of the sex-steroid-dependent genes ESR1, AR, CCND1, and TFF1 (pS2) (mRNA and/or protein).
Results We found that treatment with $p, p^{\prime}$-DDE induced a doseresponse increase in the proliferation of CAMA-1 cells when cultivated in the presence of physiological concentrations of estrogens and androgens, but not in the absence of sex steroids in the cell culture medium. A similar effect of $p, p^{\prime}-\mathrm{DDE}$ was noted on the proliferation of MCF7-AR1 cells, an estrogenresponsive cell line that was genetically engineered to overexpress the AR. DHT added together with $E_{2}$ to the cell culture medium decreased the recruitment of CAMA-1 cells in the $S$ phase and the expression of ESR1 and CCND1 by comparison with cells treated with $E_{2}$ alone. These androgenmediated effects were blocked with similar efficacy by $p, p^{\prime}-\mathrm{DDE}$ and the potent antiandrogen hydroxyflutamide.

Conclusion Our results suggest that $p, p^{\prime}-\mathrm{DDE}$ could increase breast cancer progression by opposing the androgen signalling pathway that inhibits growth in hormone-responsive breast cancer cells. The potential role of environmental antiandrogens in breast carcinogenesis deserves further investigation.

\section{Introduction}

Breast cancer is the most common cancer in women, with more than 1,000,000 new cases occurring in the year 2000 worldwide [1]. Risk factors for the disease include high plasma estrogen levels [2], high levels of expression of estrogen receptors (ERs) in mammary tissue [3,4], and high breast den- sity as revealed by mammography screening [5]. The administration of antiestrogens constitutes the most useful treatment for hormone-dependent breast cancer [6] and was shown to be effective in preventing breast cancer in clinical trials [7].

In view of the pivotal role of estrogens in the pathogenesis of breast cancer, exposure to xenobiotics that possess

ANOVA $=$ analysis of variance; $\mathrm{AR}=$ androgen receptor; $\mathrm{bp}=$ base pairs; $\mathrm{DCC}-\mathrm{FBS}=$ dextran-coated charcoal-treated fetal bovine serum; $\mathrm{DHT}=$ dihydrotestosterone; DMEM = Dulbecco's modified Eagle's medium; $E_{2}=17 \beta$-estradiol; $E R=$ estrogen receptor; $F B S=$ fetal bovine serum; OHF = hydroxyflutamide; $\mathrm{PBS}=$ phosphate-buffered saline; $\mathrm{PCR}=$ polymerase chain reaction; $p, p^{\prime}$-DDE = 1,1-dichloro-2,2-bis( $p$-chlorophenyl)ethylene; $\mathrm{RPMI}=$ Roswell Park Memorial Institute; $\mathrm{Tm}=$ annealing temperature. 
estrogenic properties, referred to as xenoestrogens, has been suggested to explain the increase in the incidence of breast cancer noted over the last four decades in industrialized countries. In vitro studies revealed that the loss of normal cell cycle control in hormone-dependent breast cancer cells can result from treatment with xenoestrogens as indicated by increased cell proliferation and modulation of estrogen-sensitive molecular parameters $[8,9]$. However, the sum of evidence from several epidemiological studies that investigated the relationship between breast cancer and exposure to persistent organochlorines, some of them with known estrogenic properties, does not support a link between any of these compounds and breast cancer risk $[10,11]$.

Environmental compounds that bind the androgen receptor (AR) constitute another class of endocrine disruptors that have received growing interest over the last decade [12,13]. Androgens control the proliferation of mammary epithelial cells in nonhuman primates $[14,15]$ as well as that of several breast cancer cell lines $[16,17]$. Androgens were shown to be effective in complementing the treatment of hormone-dependent breast cancer [18]. Furthermore, androgenic compounds can induce a remission after failure of antiestrogenic therapy (reviewed in [19]). One, therefore, may anticipate that exposure to antiandrogens could increase breast cancer risk or favor its progression.

1,1-dichloro-2,2-bis( $p$-chlorophenyl)ethylene ( $p, p^{\prime}$-DDE), the main DDT (1,1,1-trichloro-2,2-bis [ $p$-chlorophenyl]ethane) metabolite, is a highly persistent molecule that accumulates in body fat with age [20] and is a potent androgen antagonist [12]. In the course of a case-control study on organochlorine and breast cancer, we previously reported that, among cases, plasma $p, p^{\prime}$-DDE concentrations were associated with the aggressiveness of breast cancer [21]. We speculated that this relationship could be explained by the antiandrogenic action of the compound on breast cancer cells that would favor their proliferation and in turn breast cancer progression. To test this hypothesis, we used CAMA-1 breast cancer cells cultivated in the presence of physiologically relevant concentrations of sex hormones as an in vitro model of breast cancer progression. Both ER alpha (ER $\alpha)$ and AR are expressed in CAMA-1 cells; estrogens stimulate their proliferation, whereas androgens oppose the estrogen-induced proliferative effect [22]. Here, we show that $p, p^{\prime}-\mathrm{DDE}$ can markedly increase the proliferation of CAMA-1 cells in conditions in which estrogens and androgens are competing for the control of cell cycle gene expression.

\section{Materials and methods Reagents}

17ß-estradiol $\left(E_{2}\right)$ was purchased from Sigma-Aldrich (St. Louis, MO, USA) and dihydrotestosterone (DHT) from Steraloids, Inc. (Newport, RI, USA), whereas hydroxyflutamide (OHF) was kindly donated by Schering-Plough Corporation
(Kenilworth, NJ, USA). These compounds were dissolved in ethanol. $p, p^{\prime}$-DDE was purchased from Cerilliant Corporation (Round Rock, TX, USA) and was dissolved in dimethylsulfoxide. Final concentrations of vehicles in the cell culture medium were $0.1 \%$ (vol/vol). Aprotinin, leupeptin, phenylmethylsulfonyl fluoride, and sodium orthovanadate were purchased from Sigma-Aldrich.

\section{Cell proliferation assays}

CAMA-1 and MCF-7 cells were purchased from the American Type Culture Collection (Manassas, VA, USA). MCF7-AR1 cells were kindly provided by Ana M Soto (Tufts University, Medford, MA, USA). CAMA-1 cells were maintained in phenol red-free Roswell Park Memorial Institute (RPMI) medium supplemented with 10\% (vol/vol) fetal bovine serum (FBS) from Wisent Inc. (St.-Bruno, QC, Canada), $1.0 \mathrm{mM}$ pyruvate, 2.0 $\mathrm{mM}$ L-glutamine, $0.1 \mu \mathrm{g} / \mathrm{mL}$ streptomycin, and $0.1 \mathrm{U} / \mathrm{mL}$ penicillin in a humidified atmosphere of $5 \% \mathrm{CO}_{2}$ at $37^{\circ} \mathrm{C}$. Two thousand cells per well were seeded in $200 \mu \mathrm{L}$ phenol red-free RPMI-10\% FBS in 96-well plates (6 wells per treatment) and were incubated during 24 hours at $37^{\circ} \mathrm{C}$. The complete medium was then substituted for FBS-free medium for a 24hour period. On day 1 of the experiment, the FBS-free medium was replaced by a medium containing $10 \%$ dextran-coated charcoal-treated FBS (DCC-FBS) from Wisent Inc., the hormones, and test chemicals (or vehicles). Cells were grown over a 9-day period with a medium replacement every 3 days. The medium was then removed and nucleic acids were stained using the CyQuant ${ }^{\circledR}$ kit purchased from Molecular Probes Inc. (now part of Invitrogen Corporation, Carlsbad, CA, USA) as described by the manufacturer. Cell proliferation for the control treatment was arbitrarily set at 1 , and results were expressed as fold induction over the control.

MCF-7 and MCF7-AR1 cells were maintained in phenol redfree Dulbecco's modified Eagle's medium (DMEM) supplemented with $10 \%$ (vol/vol) FBS, $1.0 \mathrm{mM}$ pyruvate, $2.0 \mathrm{mM} \mathrm{L}$ glutamine, $0.1 \mu \mathrm{g} / \mathrm{mL}$ streptomycin, $0.1 \mathrm{U} / \mathrm{mL}$ penicillin, and 1 $\mu \mathrm{g} / \mathrm{mL}$ insulin in a humidified atmosphere of $5 \% \mathrm{CO}_{2}$ at $37^{\circ} \mathrm{C}$. One thousand cells per well were seeded in $200 \mu \mathrm{L}$ of phenol red-free DMEM-10\% FBS in 96-well plates ( 6 wells per treatment) and were incubated during 24 hours at $37^{\circ} \mathrm{C}$. The complete medium was removed and cells were washed with phosphate-buffered saline (PBS). Then a medium containing $10 \%$ DCC-FBS, the hormones, and test chemicals (or vehicles) were added. Cells were grown over a 6-day period without medium replacement, and proliferation was assessed as described above for CAMA-1 cells.

\section{Cell cycle analysis}

Fifty thousand cells per well were seeded in $1 \mathrm{~mL}$ phenol redfree RPMI-10\% FBS in 24-well plates and incubated during 24 hours at $37^{\circ} \mathrm{C}$. The medium was replaced by FBS-free medium during 48 hours to promote G0/G1 synchronization [23]. FBS-free medium was then replaced by a medium 
containing 10\% DCC-FBS, hormones, and test chemicals (or vehicles) for a 24 -hour incubation period at $37^{\circ} \mathrm{C}$. Cells were harvested following trypsinization, fixed in $70 \%$ ethanol for 30 minutes at $-30^{\circ} \mathrm{C}$, and stained with propidium iodide $(50 \mu \mathrm{g} /$ $\mathrm{mL}$ ) in PBS containing $40 \mathrm{U} / \mathrm{mL}$ RNase $A$ for 1 hour at $37^{\circ} \mathrm{C}$. The DNA content in each cell was determined by flow cytometry analysis using the Wallac 1420 Multilabel Counter from PerkinElmer Life and Analytical Sciences, Inc. (Waltham, MA, USA).

\section{Gene expression levels}

Two million cells were seeded into $10-\mathrm{cm}$ dishes in $10 \mathrm{~mL}$ of phenol red-free RPMI-10\% FBS and were incubated during 24 hours at $37^{\circ} \mathrm{C}$. The complete medium was then substituted for FBS-free medium for a 24-hour period. The FBS-free medium was subsequently replaced by a medium containing $10 \%$ DCC-FBS, the hormones, and test chemicals (or vehicles), and cells were grown over a 24-hour period. Duplicate cell cultures were used for each treatment: one dish was used for RNA and the other for total cell extracts. RNA was isolated with TRIzol ${ }^{\circledR}$ from Gibco (now part of Invitrogen Corporation) as described by the manufacturer and diluted in $40 \mu \mathrm{L}$ of diethyl pyrocarbonate-treated $\mathrm{H}_{2} \mathrm{O}$. mRNAs were reverse-transcribed by Super Script $\|^{\mathrm{TM}}$ using Oligo(dt) primer from Invitrogen Corporation as described by the manufacturer in a final volume of $50 \mu \mathrm{L}$. An amount of $500 \mathrm{ng}$ of total RNA was included as template for each reaction. The amount of cDNA used for polymerase chain reaction (PCR) was adjusted for each target gene. To assess ESR1 mRNA (forward primer: 5'AATTCAGATAATCGACGCCAG-3'; reverse: 5'-GTGTTTCAACATTCTCCCTC-CTC-3'; annealing temperature (Tm) $=58^{\circ} \mathrm{C} ; 344$ base pairs [bp]) [24], a 10- $\mu \mathrm{L}$ aliquot of cDNA was used compared with $1 \mu \mathrm{L}$ for $\beta$-actin (forward primer: 5 'CGTGACATTAAGGAGAAGCTGTGC-3'; reverse: 5'CTCAGGAGGAGCAATGATCTTGAT-3'; $\mathrm{Tm}=58^{\circ} \mathrm{C} ; 375$ bp) [25], while 10 and $5 \mu \mathrm{L}$ of amplified product were loaded on an $8 \%$ polyacrylamide gel for ESR 1 and $\beta$-actin, respectively. To evaluate mRNAs for CCND1 (forward primer: 5'CGGAGGAGAACAAACAGATC-3'; reverse: 5'-GGGTGTGCAAGCCAGGTCCA-3'; Tm $=55^{\circ} \mathrm{C} ; 350 \mathrm{bp}$ ) [26] and AR (forward primer: 5'-GTCAAAAGCGAAATGGGCCCC-3'; reverse: 5'-CTTCTGGGTTGTCTCCTCAGT-3'; $\mathrm{Tm}=60^{\circ} \mathrm{C}$; 420 bp) [27], we used $5-\mu \mathrm{L}$ aliquots of cDNA for both genes and a $2-\mu \mathrm{L}$ aliquot for $\beta$-actin while $10 \mu \mathrm{L}$ of amplified products was loaded on the gel. To evaluate mRNAs for TFF1 (forward primer: 5'-TTTGGAGCAGAGAGGAGGCAATGG-3'; reverse: 5'-TGGTATTAGGATAGAAGCACCAGGG-3'; Tm = $58^{\circ} \mathrm{C} ; 240 \mathrm{bp}$ ) [28], we used $2-\mu \mathrm{L}$ aliquots of cDNA and a 2$\mu \mathrm{L}$ aliquot for $\beta$-actin while $10 \mu \mathrm{L}$ of amplified products was loaded on the gel. Taq DNA polymerase and deoxynucleotides (Roche Diagnostics, Basel, Switzerland) were used as described by the manufacturer in a $50-\mu \mathrm{L}$ final volume. The PCR settings were adjusted to complete each reaction within the linear portion of amplification. PCR conditions were one 5minute cycle at $95^{\circ} \mathrm{C}, 25$ ( $\beta$-actin) or 30 cycles (target
mRNAs) each comprising a 30 -second step at $95^{\circ} \mathrm{C}$, followed by a 30 -second step at primer-specific $\mathrm{Tm}$ and a 45 -second step at $72^{\circ} \mathrm{C}$, and one last cycle of 7 minutes at $72^{\circ} \mathrm{C}$. Negative controls were included for each reaction. PCR products were stained with ethidium bromide and captured with a 16bit camera. Densitometry was determined by Quantity One 1D Software Analysis from Bio-Rad Laboratories, Inc. (Hercules, CA, USA) and normalized with $\beta$-actin.

\section{Immunoblotting}

Floating cells were recovered with the medium and pooled with the adherent cells that were harvested by scraping in 2 $\mathrm{mL}$ of ice-cold PBS, centrifuged, and resuspended in $600 \mu \mathrm{L}$ of lysis buffer containing 50 mM Hepes, pH 7.5; 1 mM EGTA (ethylene glycol tetraacetic acid), $\mathrm{pH} 8 ; 150 \mathrm{mM} \mathrm{NaCl} ; 1.5$ $\mathrm{mM} \mathrm{MgCl} 2 ; 10 \mathrm{mM}$ sodium pyrophosphate; $200 \mu \mathrm{M}$ sodium orthovanadate; 100 mM NaF; 1\% Triton X-100; 10\% glycerol; and a protease inhibitor cocktail from EMD Biosciences, Inc. (San Diego, CA, USA). Insoluble material was removed by centrifugation (10 minutes at $13,000 \mathrm{~g}$ ). Thirty micrograms of the cellular extract was resolved on PROTEAN ${ }^{\circledR}$ ॥ (Bio-Rad Laboratories, Inc.) 10\% SDS-polyacrylamide gels. The proteins were electroblotted onto $0.45-\mu \mathrm{M}$ polyvinyl difluoride membranes purchased from Millipore Corporation (Billerica, MA, USA). Membranes were blocked at room temperature for 1 hour in PBS containing 5\% (wt/vol) dried milk and incubated 2 hours at $37^{\circ} \mathrm{C}$ with the specific antibody diluted in PBS containing 1\% (wt/vol) dried milk. Antibodies against ER $\alpha, A R$, and cyclin D1 were purchased from Santa Cruz Biotechnology, Inc. (Santa Cruz, CA, USA), and anti-actin was from Cedarlane Laboratories Limited (Burlington, ON, Canada). Membranes were washed in PBS containing 0.1\% (vol/vol) Tween 20 followed by a 1 -hour incubation with specific immunoglobulin $\mathrm{G}$ horseradish peroxidase-conjugated antibodies from Jackson ImmunoResearch Laboratories, Inc. (West Grove, PA, USA) and then incubated in Immun Star HRP Substrate (Bio-Rad Laboratories, Inc.) as described by the manufacturer. Signals were analyzed as described above for reverse transcription-polymerase chain reaction and were normalized for actin within the same membrane according to the method of Liao and colleagues [29].

\section{Statistical analyses}

Concentration-response relationships were tested using linear regression analysis. Group means were compared using an analysis of variance (ANOVA) with specific contrasts or an ANOVA followed by the Bonferroni post hoc test. One-tail tests were performed for cell proliferation experiments because of a priori hypotheses regarding treatment effects (that is, inhibition for androgens and induction for antiandrogens). All other tests were two-sided. All statistical analyses were performed using the SPSS for Windows software (version 11.5.0; SPSS Inc., Chicago, IL, USA). 
Figure 1

(a)

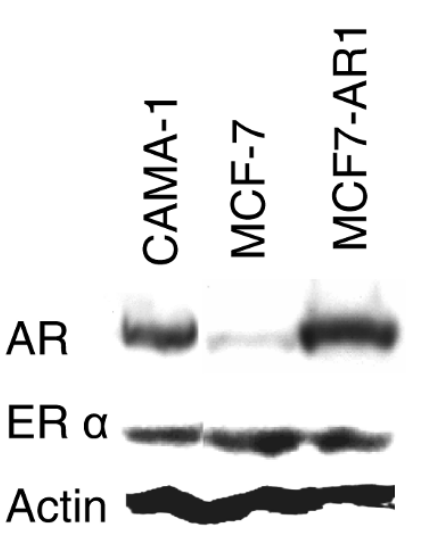

(b)

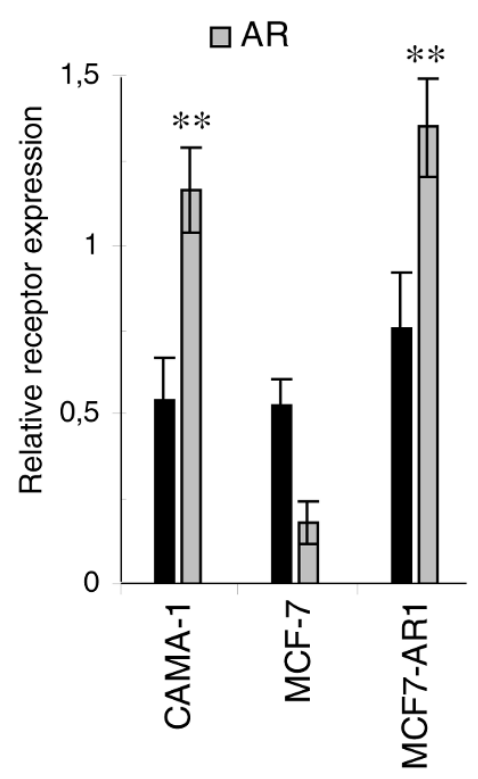

Expression of the estrogen receptor alpha $(E R \alpha)$ and the androgen receptor (AR) in CAMA-1, MCF-7, and MCF7-AR1 breast cancer cell lines at the protein level. Cell extracts were prepared during exponential proliferation in maintenance medium containing $10 \%$ fetal bovine serum. Immunoblots were performed as described in Materials and methods. (a) A representative immunoblot. (b) Relative expression of sex steroid receptors quantified to actin content. Each bar represents the mean \pm standard error of the mean of four independent experiments. Double asterisk indicates $P<0.01$ versus wild-type MCF-7 cells as determined by an analysis of variance followed by a Bonferroni post hoc test.

\section{Results}

\section{Level of expression of ER $\alpha$ and $A R$ in cell lines}

Figure 1 displays the relative levels of ER $\alpha$ and AR in CAMA1, MCF7-AR1, and wild-type MCF-7 cells. CAMA-1 and MCF7-AR1 cells expressed, respectively, 6.5 -fold $(P<0.01)$ and 7.5 -fold $(P<0.01)$ more AR proteins compared with wildtype MCF-7 cells, whereas ER $\alpha$ expression levels were not dif- ferent among the cell lines. Because of their high levels of expression of ER $\alpha$ and AR, CAMA-1 and MCF7-AR1 cells were used to investigate the capacity of $p, p^{\prime}$-DDE to disrupt the estrogen-androgen balance and increase cell proliferation.

\section{Cell proliferation}

Before testing the effect of the environmental antiandrogen $p, p^{\prime}$-DDE on cell growth, we first assessed the proliferative response of CAMA- 1 cells in the presence of estrogens and androgens in the cell culture medium over a 9-day period. Figure $2 \mathrm{a}$ shows the concentration-response relationship for $\mathrm{E}_{2}$ induced proliferation of CAMA-1 cells. We used a 100-pM concentration of $E_{2}$, which generates near maximal proliferation, in combination with increasing concentrations of DHT and observed an inverse dose-response relationship between androgen concentrations (log-transformed) and cell proliferation (regression coefficient $[\beta]=-0.887 ; P<0.001$ ) (Figure $2 b)$. Combined treatment with 100,500 , or $1,000 \mathrm{pM}$ DHT reduced the $\mathrm{E}_{2}$-induced proliferative response by $27 \%(P<$ $0.05), 54 \%(P<0.001)$, and 60\% $(P<0.001)$, respectively.

To investigate the potential of $p, p^{\prime}$-DDE to increase the proliferation of CAMA- 1 cells cultivated in the presence of endogenous estrogens and androgens, increasing concentrations of $p, p^{\prime}$-DDE were added to the cell culture medium together with $\mathrm{E}_{2}$ and DHT. $p, p^{\prime}$-DDE induced concentration-related increases in CAMA-1 cell proliferation in the presence of 100 $\mathrm{pM} \mathrm{E}_{2}$ and DHT added at a concentration of $100 \mathrm{pM}(\beta=$ $0.674, P<0.001$; Figure 3a), $500 \mathrm{pM}(\beta=0.629, P<0.001$; Figure $3 \mathrm{~b})$, or $1,000 \mathrm{pM}(\beta=0.663, P<0.001$; Figure $3 \mathrm{c})$. Concentrations of $p, p^{\prime}$-DDE as low as $2 \mu \mathrm{M}$ caused a statistically significant increase in cell proliferation compared with the $\mathrm{E}_{2}+\mathrm{DHT}$ treatment $(P<0.01$; Figure $3 \mathrm{a}, \mathrm{b})$; the $5-\mu \mathrm{M}$ concentration completely abolished the inhibitory effect of DHT on cell proliferation. In the absence of sex steroid hormones, $p, p^{\prime}$ DDE added to the cell culture medium induced only a slight proliferative response (1.3-fold induction at $10 \mu \mathrm{M}, P<0.01$; Figure 3d).

The capacity of $p, p^{\prime}-\mathrm{DDE}$ to increase breast cancer cell proliferation in the presence of sex steroids was also tested in MCF7-AR1 cells. Szelei and colleagues [30], who genetically engineered these cells that overexpress the AR, previously reported that $D H T$ added together to $E_{2}$ decreased the proliferation of MCF7-AR1 cells compared with treatment with $E_{2}$ alone. We observed that $p, p^{\prime}-\mathrm{DDE}$ induced a concentrationrelated increase in MCF7-AR1 proliferation in the presence of $10 \mathrm{pM} \mathrm{E}_{2}$ and $100 \mathrm{pM} \mathrm{DHT}(\beta=0.513, P=0.01$; Figure $4 \mathrm{a})$. A 2- $\mu \mathrm{M}$ concentration of $p, p^{\prime}-\mathrm{DDE}$ caused a 2 -fold increase in cell proliferation compared with the $\mathrm{E}_{2}+\mathrm{DHT}$ treatment $(P<$ 0.05). In the absence of sex steroid hormones, $p, p^{\prime}-\mathrm{DDE}$ added to the cell culture medium also induced a significant proliferative response (2.9- and 3.6-fold induction at 5 and 10 $\mu \mathrm{M}$, respectively, $P<0.001$; Figure $4 \mathrm{~b}$ ). 
Figure 2

(a)

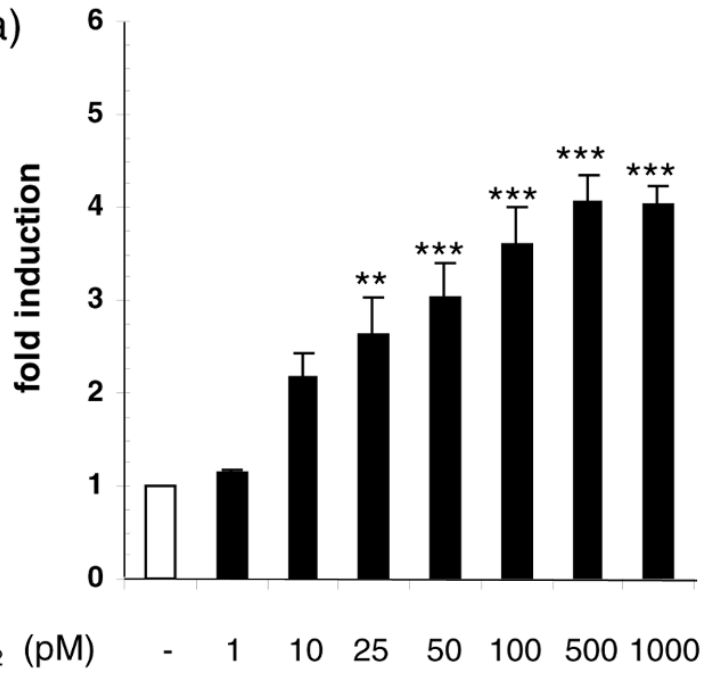

(b)

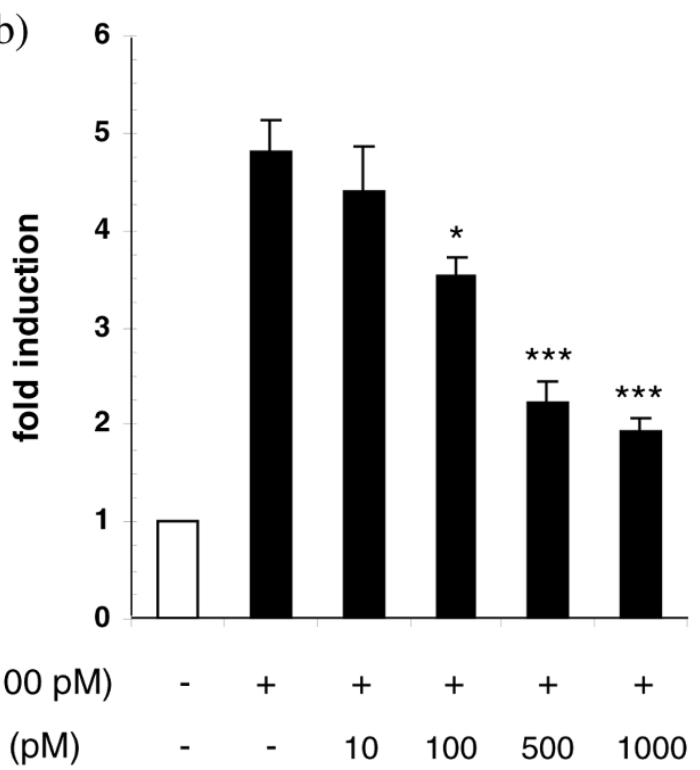

Effects of $17 \beta$-estradiol $\left(\mathrm{E}_{2}\right)$ and dihydrotestosterone $(\mathrm{DHT})$ on the proliferation of CAMA-1 cells. $E_{2}$ induces cell proliferation in a concentration-dependent manner (a) while increasing concentrations of DHT inhibit the proliferative response triggered by $100 \mathrm{pM} \mathrm{E}_{2}$ (b). Cell proliferation was assessed after 9 days of treatment. Each bar represents the mean \pm standard error of the mean of three (a) and four (b) independent experiments. Single asterisk indicates $P<0.05$, double asterisk $P<0.01$, and triple asterisk $P<0.001$ versus $\mathrm{E}_{2}$ treatment by an analysis of variance followed by a one-tail Bonferroni post hoc test.

\section{Recruitment of CAMA-1 cells in S phase}

To better characterize the proliferative response induced by $p, p^{\prime}$-DDE on CAMA-1 cells, we measured cell transition from the Go/G1 to the S phase after a 24-hour treatment with $p, p^{\prime}$ DDE in the presence of sex steroid hormones and compared the results to those obtained with the potent antiandrogen $\mathrm{OHF}$. Adding $1 \mathrm{nM}$ DHT in combination with $1 \mathrm{nM} \mathrm{E}_{2}$ reduced
Figure 3
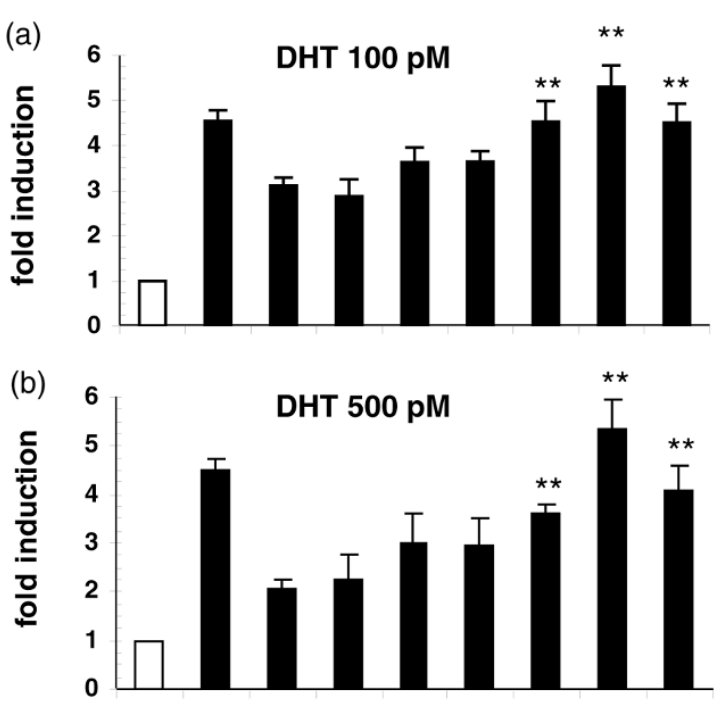

(c) 6 DHT $1000 \mathrm{pM}$

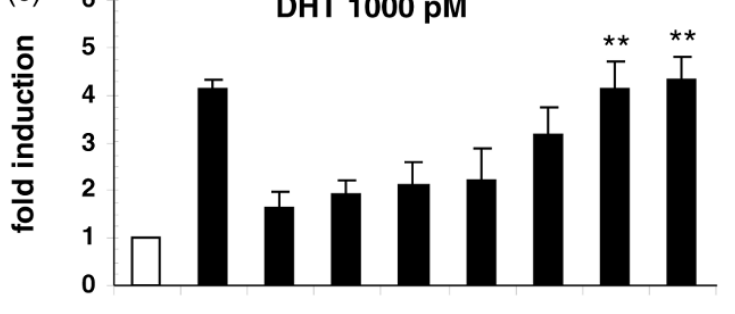

$\mathrm{E}_{2}(100 \mathrm{pM})-+++++++$ DHT $\quad-\quad-\quad++++++$

$\operatorname{DDE}(\mu \mathrm{M}) \quad-\quad-\quad-\quad \begin{array}{lllllll}0.1 & 0.5 & 1.0 & 2.0 & 5.0 & 10.0\end{array}$

(d) 6 DDE alone

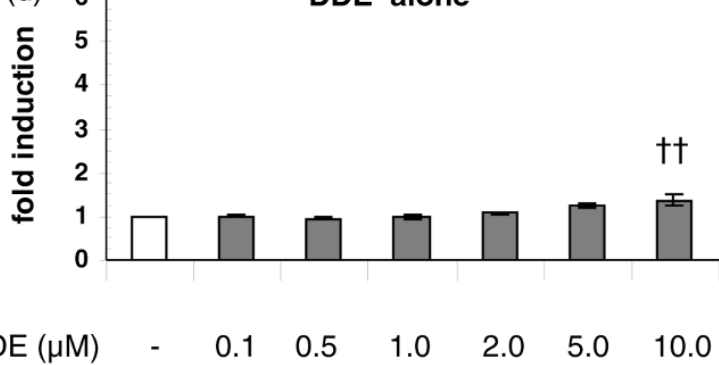

$p, p^{\prime}-\mathrm{DDE}$ increases the proliferation of CAMA-1 cells in the presence of $17 \beta$-estradiol $\left(E_{2}\right)$ and dihydrotestosterone $(\mathrm{DHT}) . \mathrm{E}_{2}$ was added at a concentration of $100 \mathrm{pM}$, and DHT was added at concentrations of $100 \mathrm{pM}$ (a), $500 \mathrm{pM}$ (b), or 1,000 pM (c). p,p'-DDE alone has little impact on CAMA-1 proliferation (d). Cell proliferation was assessed after 9 days of treatment. Each bar represents the mean \pm standard error of the mean of four independent experiments. Double asterisk indicates $P<0.01$ versus $\mathrm{E}_{2}+\mathrm{DHT}$ treatment and $+t$ indicates $P<$ 0.01 versus $0.1 \mu \mathrm{M} p, p^{\prime}-\mathrm{DDE}$ as determined by an analysis of variance followed by a one-tail Bonferroni post hoc test. $p, p^{\prime}$-DDE, 1,1-dichloro2,2-bis( $p$-chlorophenyl)ethylene.

by more than $50 \%(P<0.05)$ the percentage of cells in the $\mathrm{S}$ phase observed in the presence of $1 \mathrm{nM} \mathrm{E}_{2}$ alone (Figure 5a). 
Figure 4

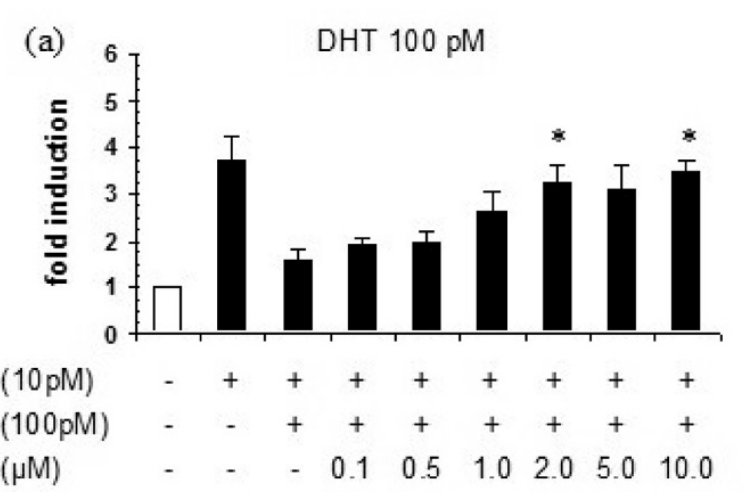

(b)

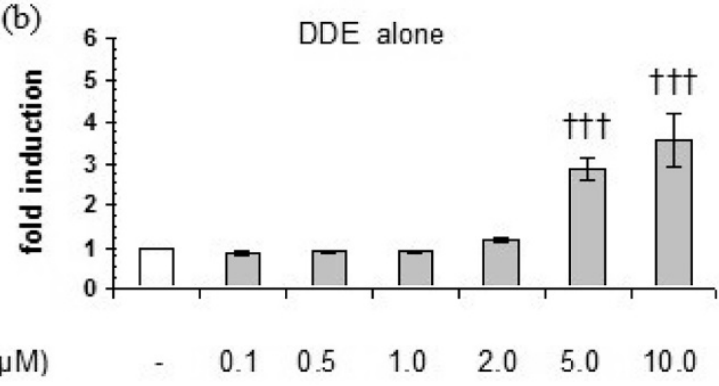

$p, p^{\prime}-\mathrm{DDE}$ increases the proliferation of MCF7-AR1 cells in the presence of $17 \beta$-estradiol $\left(E_{2}\right)$ and dihydrotestosterone $(\mathrm{DHT})(\mathrm{a})$ or when added alone to the cell culture medium (b). Cell proliferation was assessed after 6 days of treatment. Each bar represents the mean \pm standard error of the mean of four independent experiments. A single asterisk indicates $P<0.05$ versus $\mathrm{E}_{2}+\mathrm{DHT}$ treatment and $\mathrm{t+}+\mathrm{indicates}$ $P<0.001$ versus $0.1 \mu \mathrm{M} p, p^{\prime}-\mathrm{DDE}$ as determined by an analysis of variance followed by a one-tail Bonferroni post hoc test. $p, p^{\prime}$-DDE, 1,1dichloro-2,2-bis( $p$-chlorophenyl)ethylene.

The addition of either $10 \mu \mathrm{M} p, p^{\prime}$-DDE or $1 \mu \mathrm{M}$ OHF to the cell culture medium completely abolished the androgen-mediated decrease in the percentage of CAMA-1 cells entering the cell cycle $\left(P<0.05\right.$ versus $\mathrm{E}_{2}+\mathrm{DHT}$ treatment). Treatmentinduced changes in the percentage of cells in Go/G1 were of similar magnitude to those observed for the $S$ phase but in the opposite direction (Figure $5 b$ ). The proportion of cells in the $\mathrm{G} 2 / \mathrm{M}$ phase was slightly increased by the $1-\mathrm{nM} \mathrm{E}_{2}$ treatment $(P<0.05)$, but adding DHT and antiandrogens in combination with $E_{2}$ did not modify the $E_{2}$-induced response (Figure $5 c$ ).

\section{Modification of sex-steroid-dependent gene expression by $p, p^{\prime}$-DDE}

To further elucidate the mechanism underlying the induction of CAMA-1 cell proliferation by $p, p^{\prime}$-DDE, we studied the effect of a 24-hour treatment with $p, p^{\prime}-\mathrm{DDE}$ on the expression of sexhormone-sensitive genes at the mRNA level, in the presence of $\mathrm{E}_{2}$ and $\mathrm{DHT}$, and compared the results with those obtained by treating the cells with OHF in combination with the endogenous hormones. The mean cyclin D1 mRNA level was increased by $50 \%(P<0.01)$ in $\mathrm{E}_{2}$-treated cells compared with that of the control cells (Figure 6a), whereas $1 \mathrm{nM} \mathrm{DHT}$ significantly reduced this estrogenic effect $(P<0.01$ versus
Figure 5
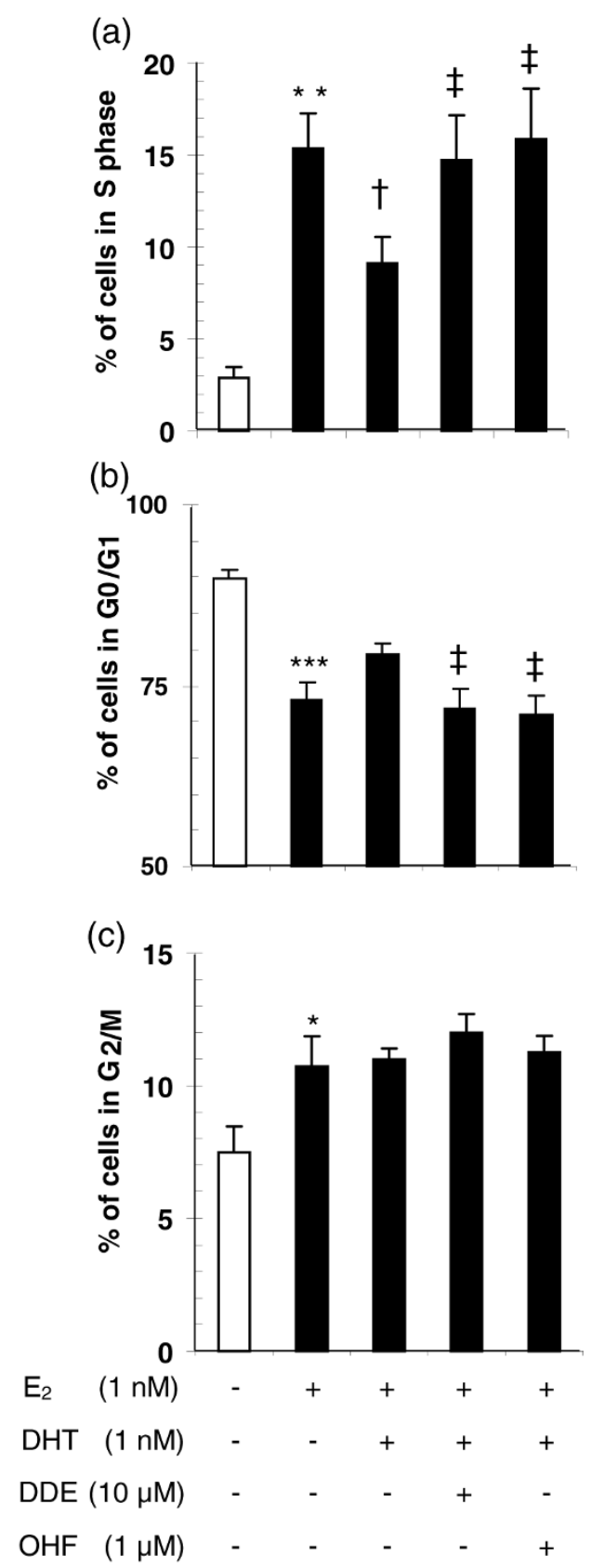

$p, p^{\prime}-\mathrm{DDE}$ increases G0/G1-S transition of CAMA-1 cells in the presence of $17 \beta$-estradiol $\left(E_{2}\right)$ and dihydrotestosterone $(D H T)$. Treatmentrelated changes are shown for the percentage of cells in $S$ (a), Go/G1 (b), and $G_{2} / M$ (c) phases. Synchronization of the cells $-90 \%$ of cells in G0/G1 and less than $3 \%$ in S phase - was induced by a 48-hour serum deprivation period. Cells were subsequently treated during 24 hours with hormones and antiandrogens (or their vehicles). Each bar represents the mean \pm standard error of the mean of four independent experiments in duplicate. Single asterisk indicates $P<0.05$, double asterisk $P<0.01$, and triple asterisk $P<0.001$ versus control, $\dagger$ indicates $P<0.05$ versus $\mathrm{E}_{2}$ treatment, and $\neq$ indicates $P<0.05$ versus $\mathrm{E}_{2}+\mathrm{DHT}$ treatment as determined by an analysis of variance with specific contrasts. OHF, hydroxyflutamide; $p, p^{\prime}$-DDE, 1,1-dichloro-2,2bis( $p$-chlorophenyl)ethylene. 
$\mathrm{E}_{2}$ alone). Treatment with either $10 \mu \mathrm{M} p, p^{\prime}-\mathrm{DDE}$ or $1 \mu \mathrm{M}$ OHF partly abolished the inhibition of cyclin D1 mRNA expression induced by $\mathrm{DHT}$, resulting in mean expression levels that are not significantly different from that induced by $E_{2}$ alone. Although $\mathrm{E}_{2}$ alone did not modulate ER $\alpha$ mRNA expression, the $E_{2}+D H T$ treatment appeared to decrease the mean expression level compared with that induced by $E_{2}$ alone (Figure $6 b$ ), whereas $p, p^{\prime}$-DDE or OHF partly offset this downregulation. However, differences between treatments did not reach statistical significance. AR mRNA mean expression level was decreased by $27 \%$ following DHT treatment compared with $\mathrm{E}_{2}$ treatment $(P<0.01$; Figure $6 \mathrm{c})$, whereas treatment with either $10 \mu \mathrm{M} p, p^{\prime}$-DDE or $1 \mu \mathrm{M}$ OHF completely antagonized this inhibition $\left(P<0.01\right.$ versus $\left.\mathrm{E}_{2}+\mathrm{DHT}\right)$. pS2 mRNA mean expression level was increased by $50 \%(P<0.01)$ following $E_{2}$ treatment compared with the control (Figure 6d). The $\mathrm{E}_{2}+\mathrm{DHT}$ treatment induced a slightly lower expression of pS2 mRNA compared with that caused by $E_{2}$ alone, but the difference was not statistically significant. $p, p^{\prime}$-DDE added together with $E_{2}$ and DHT induced a greater pS2 mRNA expression than did the $\mathrm{E}_{2}+\mathrm{DHT}$ treatment $(P<0.05)$.

We also evaluated the modulation of cyclin D1, ER $\alpha$, and AR protein expression levels by $p, p^{\prime}$-DDE treatment in CAMA-1 cells in the presence of endogenous sex steroids. Cyclin D1 level was increased by $80 \%(P<0.01)$ in cells treated with 1 $n M E_{2}$ compared with the vehicle-treated cells (Figure 7a), whereas adding $1 \mathrm{nM} \mathrm{DHT}$ in combination with $\mathrm{E}_{2}$ blocked this increase ( $P<0.01$ versus $\mathrm{E}_{2}$ alone). The addition of either 10 $\mu \mathrm{M} p, p^{\prime}-\mathrm{DDE}$ or $1 \mu \mathrm{M} \mathrm{OHF}$ to the cell culture medium together with $\mathrm{E}_{2}$ and $\mathrm{DHT}$ completely abolished this DHT-mediated inhibition of cyclin D1 expression $\left(P<0.01\right.$ versus $\left.\mathrm{E}_{2}+\mathrm{DHT}\right)$. Whereas $E_{2}$ alone was without effect, the combined $E_{2}+D H T$ treatment markedly decreased ER $\alpha$ protein level (more than $50 \%)$ as compared with that observed following $E_{2}$ treatment or control $(P<0.05$; Figure $7 \mathrm{~b}) . p, p^{\prime}$-DDE or OHF treatment again abolished this androgen-mediated inhibition $(P<0.01$ versus $\left.E_{2}+D H T\right)$. A different response pattern was observed for AR protein expression (Figure 7c). $\mathrm{E}_{2}$ treatment decreased by $28 \%(P<0.05)$ the mean AR protein expression level compared with control, whereas AR protein level was significantly increased following the combined $\mathrm{E}_{2}+\mathrm{DHT}$ treatment compared with the value noted following $\mathrm{E}_{2}$ treatment alone $(P<$ $0.01)$. The androgen-mediated increase in $A R$ protein level was antagonized by adding OHF in the incubation medium ( $P$ $<0.05$ versus $\mathrm{E}_{2}+\mathrm{DHT}$ ) but not $p, p^{\prime}-\mathrm{DDE}$ (Figure $7 \mathrm{c}$ ).

\section{Discussion}

We tested the capacity of $p, p^{\prime}-\mathrm{DDE}$ to stimulate the proliferation of CAMA- 1 cells, a human breast adenocarcinoma cell line that expresses both the ER $\alpha$ and the AR. We showed that $p, p^{\prime}$-DDE strongly induces the proliferation of CAMA- 1 cells in a concentration-dependent manner but only when cells are grown in the presence of physiological concentrations of endogenous sex steroid hormones. When concentrations of
Figure 6
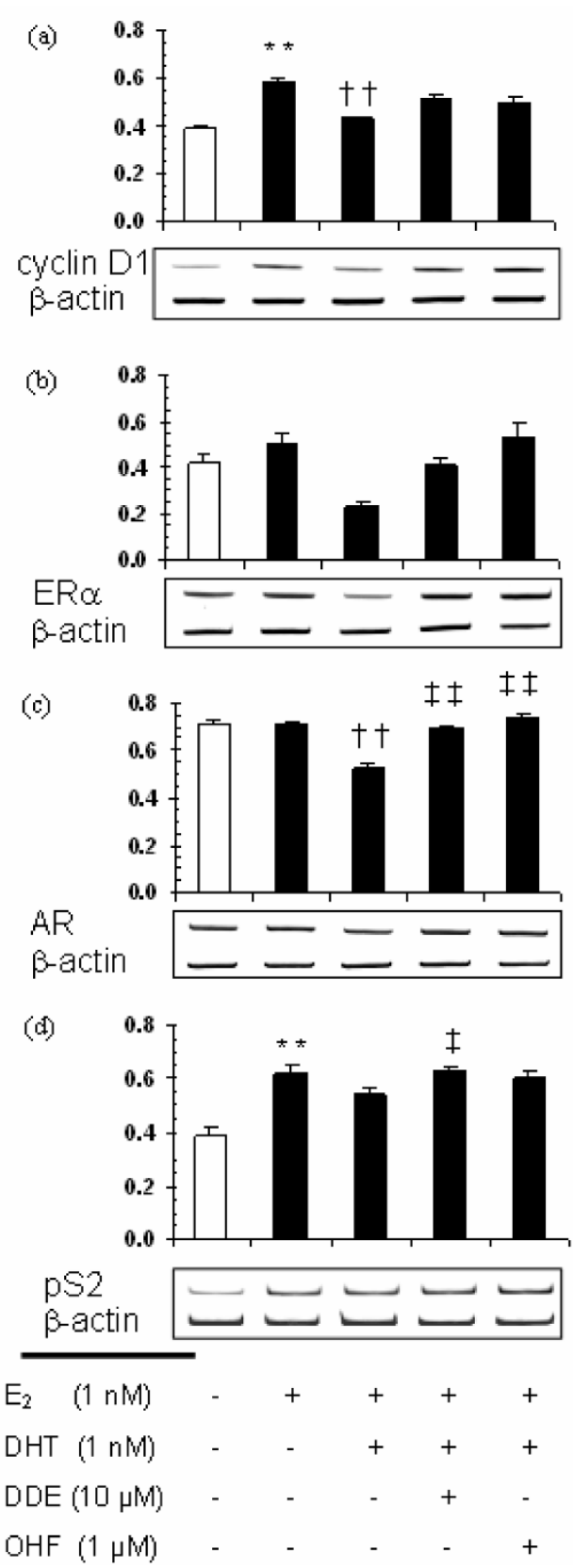

$p, p^{\prime}$-DDE modulates the expression of sex-steroid-dependent genes in CAMA- 1 cells at the mRNA level. mRNA levels were determined by a semiquantitative polymerase chain reaction after a 24-hour treatment with hormones and antiandrogens (or vehicles) as described in Materials and methods. mRNAs for CCND1 (a), ESR1 (b), AR (c), and TFF1 (d) were quantified relative to $\beta$-actin mRNA. A representative gel electrophoresis is shown below each panel. Each bar represents the mean \pm standard error of the mean of six independent experiments. Double asterisk indicates $P<0.01$ versus control, + t indicates $P<0.01$ versus $\mathrm{E}_{2}$ treatment, and $\neq$ and $\neq$ indicate, respectively, $P<0.05$ and $P<$ 0.01 versus $E_{2}+D H T$ treatment as determined by an analysis of variance with specific contrasts. AR, androgen receptor; DHT, dihydrotestosterone; $E_{2}, 17 \beta$-estradiol; $E R \alpha$, estrogen receptor alpha; OHF, hydroxyflutamide; $p, p^{\prime}$-DDE, 1,1-dichloro-2,2-bis( $p$-chlorophenyl)ethylene. 
Figure 7

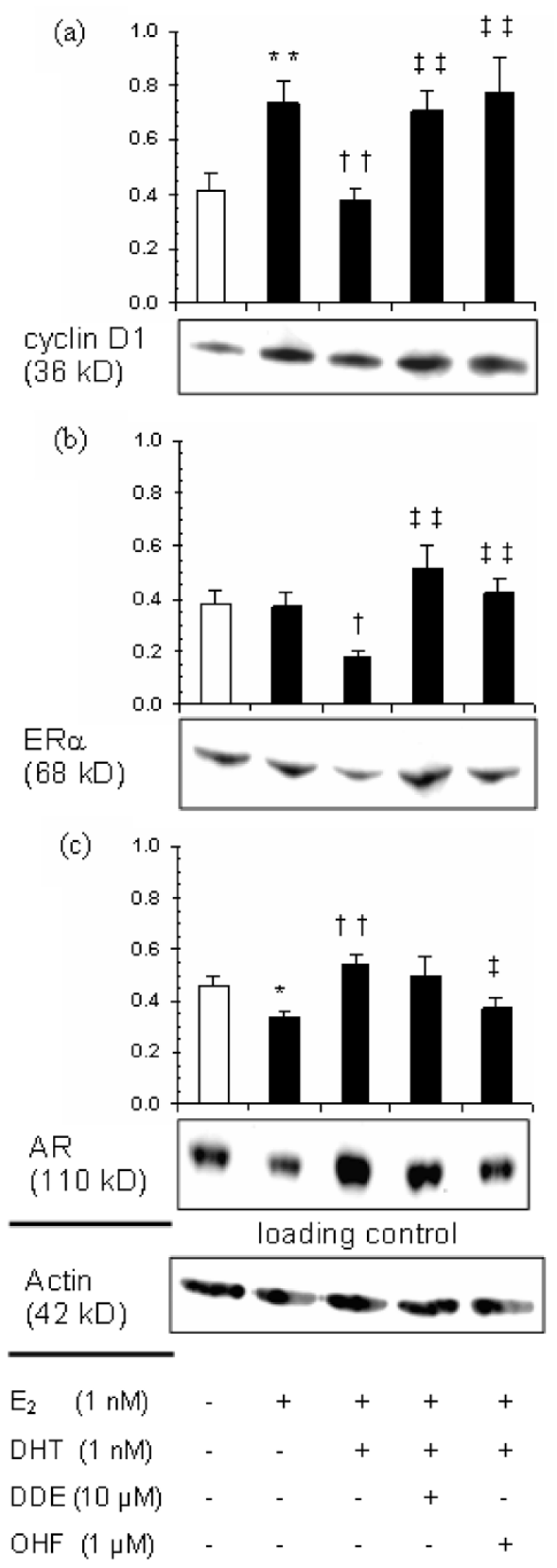

$p, p^{\prime}-\mathrm{DDE}$ modulates the expression of sex-steroid-dependent genes in CAMA-1 cells at the protein level. Immunoblots were performed after 24 hours of treatment with hormones and antiandrogens (or vehicles) as described in Materials and methods. Cyclin D1 (a), ER $\alpha$ (b), and AR (c) protein levels were quantified relative to actin content. Each bar represents the mean \pm standard error of the mean of six independent experiments. A representative immunoblot is shown below each panel. Single asterisk indicates $P<0.05$ and double asterisk $P<0.01$ versus control; + and $+\dagger$ indicate, respectively, $P<0.05$ and $P<0.01$ versus $\mathrm{E}_{2}$ treatment; and $\neq$ and $\neq$ indicate, respectively, $P<0.05$ and $P<$ 0.01 versus $E_{2}+D H T$ treatment as determined by an analysis of variance with specific contrasts. AR, androgen receptor; DHT, dihydrotestosterone; $\mathrm{E}_{2}, 17 \beta$-estradiol; $\mathrm{ER} \alpha$, estrogen receptor alpha; $\mathrm{OHF}$, hydroxyflutamide; $p, p^{\prime}$-DDE, 1,1-dichloro-2,2-bis( $p$-chlorophenyl)ethylene.
$E_{2}$ and $\mathrm{DHT}$ are such that the androgen signalling pathway partly counteracts the influence of the estrogen signalling pathway on cell proliferation, $p, p^{\prime}$-DDE blocks the $A R$, resulting in CCND1 overexpression, the recruitment of cells in the $\mathrm{S}$ phase, and in turn increased cell proliferation.

The capacity of the androgen DHT to inhibit the proliferation of CAMA-1 breast cancer cells was previously reported by Lapointe and Labrie [22]. Similarly to our results, these authors reported a dose-dependent inhibition of cell proliferation and maximal inhibition of $E_{2}$-stimulated proliferation at the 1-nM DHT concentration. Other groups have reported that androgens can inhibit the proliferation of several hormone-dependent breast cancer cell lines, including MCF-7, T47D, and ZR75-1 cells $[16,17]$. We tested these and other wild-type breast cancer cell lines, but in our hands only CAMA-1 cells responded strongly and reproducibly to androgens. We therefore elected to use CAMA-1 cells grown in the presence of estrogens and androgens as an in vitro model for investigating the role of environmental antiandrogens in breast cancer progression.

$p, p^{\prime}$-DDE also induced the proliferation of MCF7-AR1 cells in the presence of $E_{2}$ and DHT in the cell culture medium. These stably transfected cells that overexpress the AR are derived from MCF-7 cells [30], an estrogen-sensitive breast cancer cell line that has been widely used in proliferation assays for testing the estrogenic potential of chemicals (E-Screen bioassay). In contrast to results with CAMA-1 cells, $p, p^{\prime}-\mathrm{DDE}$ also increased the proliferation of MCF7-AR1 cells in the absence of sex hormones (Figure 4b). This direct proliferative effect, which is likely due to the estrogenic potential of $p, p^{\prime}-\mathrm{DDE}$, was similar to that obtained by other groups with native MCF-7 cells [31-33]. Therefore, activation of the estrogenic pathway could be responsible in part for the induction of proliferation observed when MCF7-AR1 cells were cotreated with $p, p^{\prime}$ $\mathrm{DDE}, \mathrm{E}_{2}$, and DHT (Figure 4a). Interestingly, in the presence of $E_{2}$ and DHT, the proliferation of MCF7-AR1 cells was induced by lower concentrations of $p, p^{\prime}$-DDE than those required in the absence of sex steroids. This could be explained by the greater affinity of $p, p^{\prime}-\mathrm{DDE}$ for $\mathrm{AR}$ than for $\mathrm{ER} \alpha$ [12], resulting in the predominance of the AR signalling pathway at low concentrations. $p, p^{\prime}-\mathrm{DDE}$ and several other compounds possess both antiandrogenic and estrogenic activities [34] and therefore may increase breast cancer cell proliferation through interference with both estrogenic and androgenic pathways.

Our data suggest that one of the key events in the mechanism of action through which $p, p^{\prime}-\mathrm{DDE}$ increases CAMA-1 cell proliferation is the upregulation of CCND1 expression. Indeed, we observed concomitant increases in CCND1 expression and $S$ phase entry following treatment with $p, p^{\prime}-D D E$ in the presence of sex steroids compared with responses induced by the $\mathrm{E}_{2}+\mathrm{DHT}$ treatment. This mechanism is apparently common to antiandrogens in general as similar results were 
observed with OHF. Cyclin D1 is a major regulator of the G1/ $S$ phase transition and a rate-limiting step in estrogen-induced mammary cell proliferation $[35,36]$. This oncogene has been shown to transform breast cells in transgenic mice [37] and is frequently overexpressed in primary breast cancer, especially in invasive carcinomas [38,39]. In our experiments, the cyclin D1 protein expression pattern was remarkably similar to its corresponding mRNA expression pattern, suggesting that cyclin D1 expression is mostly controlled at the mRNA level in CAMA-1 cells.

Our results also suggest that ESR1 expression is involved in the mechanism through which antiandrogens increase the expression of CCND1 in CAMA-1 cells. Effectively, we observed similar treatment-related effects for the expression of CCND1 and ESR1: DHT decreased the expression of both genes whereas treatment with either $p, p^{\prime}-\mathrm{DDE}$ or OHF increased their expression in the presence of $E_{2}$ and $D H T$. $E R \alpha$ has been shown to be an important transcription factor that acts indirectly on the CCND1 promoter [40-42]. That androgens can downregulate the expression of ER $\alpha$ was previously reported in the ZR-75-1 breast cancer cell line and in MCF7-AR1 cells $[30,43]$.

We did not observe a reduction in ER $\alpha$ protein expression following treatment of CAMA-1 cells with $E_{2}$. This result is in contrast to those reported in the literature showing that estrogens induce a downregulation of the ER $\alpha$ protein in hormonedependent breast cancer cell lines as well as in transfected ER-negative cell lines [44-49]. The estrogen-induced downregulation of ER $\alpha$ occurs mainly through the regulated degradation of the receptor protein by the $26 \mathrm{~S}$ proteasome $[49,50]$. Hence, CAMA-1 cells appear different than other breast cancer cell lines in that regard.

We found that the AR protein is downregulated by estradiol without any effect on the corresponding mRNA level. Therefore, this downregulation may occur either at the level of translation or through a decrease in AR stability. In contrast, DHT caused a significant increase in AR protein level in CAMA-1 cells. Similarly to our results, Andò and colleagues [51] observed that the activation of AR by DHT resulted in the inhibition of MCF-7 cell proliferation; this effect was accompanied by an increase in AR protein cell content.

Our results are compatible with the existence of a crosstalk between androgen and estrogen signalling pathways which controls breast cancer cell proliferation, similarly to that described by Lanzino and colleagues [52] in MCF-7 cells. These authors showed that AR activation influences ER $\alpha$ signalling by reducing ER $\alpha$ cellular content and by competition to recruit the coregulator ARA70, which although first described as a specific AR coregulator [53] also increases the transcriptional activity of ER $\alpha$ [52]. We speculate that binding of $p, p^{\prime}$ DDE to the AR would increase the amount of ARA70 available to interact with $E R \alpha$, thereby increasing the estrogenic signalling pathway and in turn cell proliferation. Additional experiments are needed to substantiate this mechanism of action in CAMA-1 cells.

Some evidence in the literature indicates that exposure to antiandrogens could increase breast cancer risk through perturbation of the androgen-estrogen crosstalk in mammary epithelial cells. Indeed, Dimitrakakis and colleagues [15] have reported an increase in mammary epithelial cell proliferation following treatment of female rhesus monkeys with flutamide (the precursor of OHF). Furthermore, a downregulation of ER $\alpha$ expression and a decrease in mammary epithelial cell proliferation were observed following treatment of ovariectomized rhesus monkeys with a combined estradiol/testosterone treatment compared with the group treated with estradiol alone [15]. ER $\alpha$ is weakly expressed in normal mammary epithelial cells and only a few cells express this gene [54], including the putative breast stem cells [55]. A rigorous control must be exerted on ER $\alpha$ expression in order to limit the number of 'at risk' and precancerous cells in the breast [54], which may be compromised by environmental antiandrogens.

Our results add biological plausibility to the association noted in our previous epidemiological study between plasma levels of $p, p^{\prime}-\mathrm{DDE}$ and the aggressiveness of breast cancer. We observed that women with breast cancer who had higher plasma concentrations of this compound were at greater risk of having a larger tumor and axillary lymph node invasion than women with lower concentrations [21]. Although the information is extremely limited, the association between organochlorines and disease severity and progression is interesting and worthy of further investigation [11]. By blocking the androgenic pathway, $p, p^{\prime}-\mathrm{DDE}$ may favor the proliferation of normal and breast cancer cells and accelerate breast cancer progression. Our results appear particularly relevant for cases with tumors expressing high levels of ER $\alpha$ and AR. In that context, it is worth mentioning that $70 \%$ to $90 \%$ of primary breast tumors express the AR (reviewed in [56]).

We also noted that $p, p^{\prime}-\mathrm{DDE}$ increased the expression of $\mathrm{pS} 2$ in CAMA-1 cells (Figure 6d), an estrogen-dependent protein that increases the migration of hormone-dependent breast cancer cells [57]. The failure of OHF to increase pS2 expression over the level induced by the $E_{2}+D H T$ treatment suggests that this effect may be due to the estrogenic activity of $p, p^{\prime}$ DDE. Normal breast cells secrete low levels of this chemoattractant trefoil protein [58]. This effect of $p, p^{\prime}$-DDE could contribute to breast cancer aggressiveness. Additional experiments with animal models are required to further support this hypothesis.

To our knowledge, this is the first report showing that $p, p^{\prime}-\mathrm{DDE}$ can significantly stimulate the proliferation of a breast cancer cell line in the presence of androgens and estrogens. Our 
model is unique in that compounds are tested for their capacity to stimulate cell proliferation in the presence of physiologically relevant concentrations of sex steroids. Although tests based on the proliferation of hormone-dependent breast cancer cells have been used extensively in the past, none of them can detect compounds that perturb the crosstalk between estrogenic and androgenic pathways [59]. This experimental model could be used to screen for compounds that can increase breast cancer progression because of their estrogenic potential, their antiandrogenic capacity, or a combination of both since many environmental estrogens are also AR antagonists [34].

\section{Conclusion}

Our study provides new evidence that environmental antiandrogens might favor breast cancer progression. Figure 8 illustrates part of the mechanism through which $p, p^{\prime}-\mathrm{DDE}$ may induce the proliferation of hormone-dependent cells in the breast. Additional investigations are under way to investigate the effect on breast cancer cell proliferation of a complex mixture of environmental chemicals which comprises compounds with estrogenic and antiandrogenic activities.

\section{Competing interests}

The authors declare that they have no competing interests.

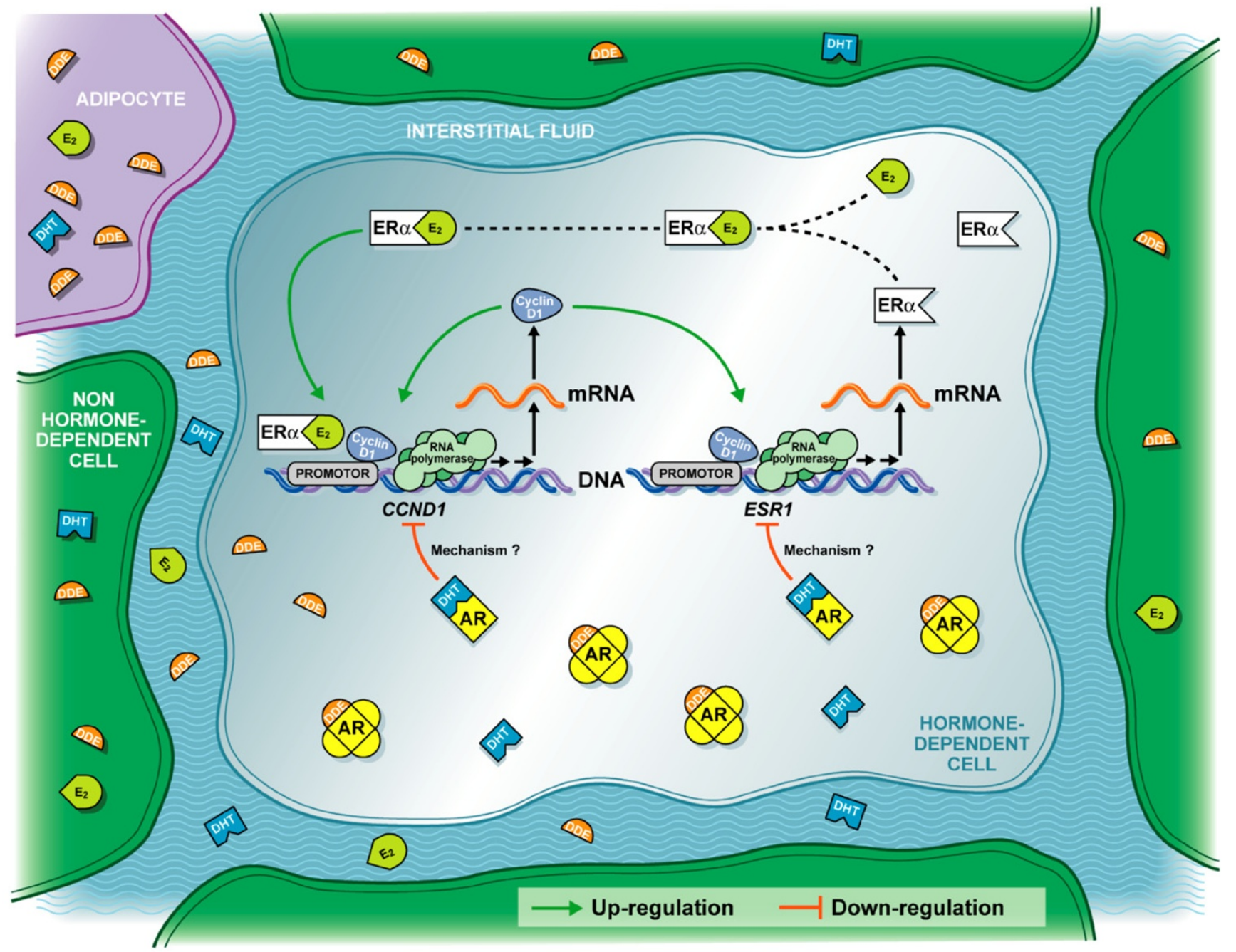

A proposed mechanism for $p, p^{\prime}$-DDE-induced proliferation of hormone-dependent cells. Lipophilic $p, p^{\prime}$-DDE is stored in adipocytes and can diffuse to reach hormone-dependent cells. $p, p^{\prime}$-DDE confers a proliferative advantage to precancerous hormone-dependent cells by blocking the androgen receptor (AR) signalling pathway that represses cell growth. Tumor development is favored through the upregulation of the oncogene CCND1, a key molecular event in the deregulation by $p, p^{\prime}$-DDE of the crosstalk between estrogen receptor alpha (ER $\left.\alpha\right)$ and the AR. $\mathrm{E}_{2}, 17 \beta$-estradiol; DHT, dihydrotestosterone; $p, p^{\prime}$-DDE, 1,1-dichloro-2,2-bis( $p$-chlorophenyl)ethylene. 


\section{Authors' contributions}

MA contributed to the study design, conducted the experiments, and wrote the first draft of the manuscript. CL contributed to the study design. PA contributed to the study design, performed statistical analyses, supervised the experiments, and prepared the final version of the manuscript. All authors read and approved the final manuscript.

\section{Acknowledgements}

The authors thank Maurice Dufour from the Centre de Recherche du Centre Hospitalier Universitaire de Québec-CHUL for performing flow cytometry analyses. This work was funded by the Canadian Breast Cancer Research Alliance (Etiology Grant \#013568).

\section{References}

1. Parkin DM, Bray FI, Devesa SS: Cancer burden in the year 2000. The global picture. Eur J Cancer 2001, 37(Suppl 8):S4-66.

2. Missmer SA, Eliassen AH, Barbieri RL, Hankinson SE: Endogenous estrogen, androgen, and progesterone concentrations and breast cancer risk among postmenopausal women. $J$ Natl Cancer Inst 2004, 96:1856-1865.

3. Kurebayashi J, Otsuki T, Kunisue H, Tanaka K, Yamamoto S, Sonoo H: Expression levels of estrogen receptor-alpha, estrogen receptor-beta, coactivators, and corepressors in breast cancer. Clin Cancer Res 2000, 6:512-518.

4. Khan SA, Rogers MA, Khurana KK, Siddiqui JF: Oestrogen receptor expression in normal breast epithelium. Eur J Cancer 2000, 36(Suppl 4):S27-S28.

5. Boyd NF, O'Sullivan B, Campbell JE, Fishell E, Simor I, Cooke G, Germanson T: Mammographic signs as risk factors for breast cancer. Br J Cancer 1982, 45:185-193.

6. Wallgren A, Baral E, Glas U, Karnström L, Nordenskiöld B, Theve NO, Silfverswärd C: Adjuvant tamoxifen treatment in postmenopausal patients with operable breast cancer. J Steroid Biochem 1985, 23:1161-1162.

7. Fisher B, Costantino JP, Wickerham DL, Redmond CK, Kavanah M, Cronin WM, Vogel V, Robidoux A, Dimitrov N, Atkins J, Daly M, Wieand S, Tan-Chiu E, Ford L, Wolmark N: Tamoxifen for prevention of breast cancer: report of the National Surgical Adjuvant Breast and Bowel Project P-1 Study. J Natl Cancer Inst 1998, 90:1371-1388.

8. Jorgensen M, Vendelbo B, Skakkebaek NE, Leffers H: Assaying estrogenicity by quantitating the expression levels of endogenous estrogen-regulated genes. Environ Health Perspect 2000, 108:403-412.

9. Diel P, Olff S, Schmidt S, Michna H: Effects of the environmental estrogens bisphenol A, o,p'-DDT, p-tert-octylphenol and coumestrol on apoptosis induction, cell proliferation and the expression of estrogen sensitive molecular parameters in the human breast cancer cell line MCF-7. J Steroid Biochem Mol Biol 2002, 80:61-70.

10. López-Cervantes M, Torres-Sánchez L, Tobías A, López-Carrillo L: Dichlorodiphenyldichloroethane burden and breast cancer risk: a meta-analysis of the epidemiologic evidence. Environ Health Perspect 2004, 112:207-214.

11. Mendez MA, Arab L: Organochlorine compounds and breast cancer risk. Pure Appl Chem 2003, 75:1973-2015.

12. Kelce WR, Stone CR, Laws SC, Gray LE, Kemppainen JA, Wilson EM: Persistent DDT metabolite $p, p^{\prime}-D D E$ is a potent androgen receptor antagonist. Nature 1995, 375:581-585.

13. Wilson VS, Lambright C, Ostby J, Gray LE Jr: In vitro and in vivo effects of 17 beta-trenbolone: a feedlot effluent contaminant. Toxicol Sci 2002, 70:202-211.

14. Zhou J, Ng S, Adesanya-Famuiya O, Anderson K, Bondy CA: Testosterone inhibits estrogen-induced mammary epithelial proliferation and suppresses estrogen receptor expression. FASEB J 2000, 14:1725-1730.

15. Dimitrakakis C, Zhou J, Wang J, Belanger A, LaBrie F, Cheng C, Powell D, Bondy C: A physiologic role for testosterone in limiting estrogenic stimulation of the breast. Menopause 2003, 10:292-298.
16. Birrell SN, Bentel JM, Hickey TE, Ricciardelli C, Weger MA, Horsfall DJ, Tilley WD: Androgens induce divergent proliferative responses in human breast cancer cell lines. J Steroid Biochem Mol Biol 1995, 52:459-467.

17. Ortmann J, Prifti S, Bohlmann MK, Rehberger-Schneider S, Strowitzki T, Rabe T: Testosterone and $\mathbf{5}$ alpha-dihydrotestosterone inhibit in vitro growth of human breast cancer cell lines. Gynecol Endocrinol 2002, 16:113-120.

18. Tormey DC, Lippman ME, Edwards BK, Cassidy JG: Evaluation of tamoxifen doses with and without fluoxymesterone in advanced breast cancer. Ann Intern Med 1983, 98:139-144.

19. Colleoni M, Coates A, Pagani O, Goldhirsch A: Combined chemo-endocrine adjuvant therapy for patients with operable breast cancer: still a question? Cancer Treat Rev 1998, 24:15-26.

20. Guttes S, Failing K, Neumann K, Kleinstein J, Georgii S, Brunn H: Chlororganic pesticides and polychlorinated biphenyls in breast tissue of women with benign and malignant breast disease. Arch Environ Contam Toxicol 1998, 35:140-147.

21. Demers A, Ayotte P, Brisson J, Dodin S, Robert J, Dewailly E: Risk and aggressiveness of breast cancer in relation to plasma organochlorine concentrations. Cancer Epidemiol Biomarkers Prev 2000, 9:161-166.

22. Lapointe J, Labrie C: Role of the cyclin-dependent kinase inhibitor p27(Kip1) in androgen-induced inhibition of CAMA-1 breast cancer cell proliferation. Endocrinology 2001, 142:4331-4338.

23. Leung BS, Potter AH: Mode of estrogen action on cell proliferative kinetics in CAMA-1 cells. I. Effect of serum and estrogen. Cancer Invest 1987, 5:187-194.

24. Enmark E, Pelto-Huikko M, Grandien K, Lagercrantz S, Lagercrantz J, Fried G, Nordenskjöld M, Gustafsson JA: Human estrogen receptor beta-gene structure, chromosomal localization, and expression pattern. J Clin Endocrinol Metab 1997, 82:4258-4265.

25. Lipman ML, Stevens AC, Bleackley RC, Helderman JH, McCune TR, Harmon WE, Shapiro ME, Rosen S, Strom TB: The strong correlation of cytotoxic $T$ lymphocyte-specific serine protease gene transcripts with renal allograft rejection. Transplantation 1992, 53:73-79.

26. Willey JC, Crawford EL, Jackson CM, Weaver DA, Hoban JC, Khuder SA, DeMuth JP: Expression measurement of many genes simultaneously by quantitative RT-PCR using standardized mixtures of competitive templates. Am J Respir Cell Mol Biol 1998, 19:6-17.

27. Ito K, Suzuki T, Akahira J, Moriya T, Kaneko C, Utsunomiya H, Yaegashi N, Okamura K, Sasano H: Expression of androgen receptor and 5alpha-reductases in the human normal endometrium and its disorders. Int J Cancer 2002, 99:652-657.

28. Gillesby BE, Zacharewski TR: pS2 (TFF1) levels in human breast cancer tumor samples: correlation with clinical and histological prognostic markers. Breast Cancer Res Treat 1999, 56:253-265.

29. Liao J, Xu X, Wargovich MJ: Direct reprobing with anti-betaactin antibody as an internal control for western blotting analysis. Biotechniques 2000, 28:216-218.

30. Szelei J, Jimenez J, Soto AM, Luizzi MF, Sonnenschein C: Androgen-induced inhibition of proliferation in human breast cancer MCF7 cells transfected with androgen receptor. Endocrinology 1997, 138:1406-1412.

31. Andersen HR, Andersson AM, Arnold SF, Autrup H, Barfoed M, Beresford NA, Bjerregaard P, Christiansen LB, Gissel B, Hummel $\mathrm{R}$, Jørgensen EB, Korsgaard B, Le Guevel R, Leffers H, McLachlan J, Møller A, Nielsen JB, Olea N, Oles-Karasko A, Pakdel F, Pedersen KL, Perez P, Skakkeboek NE, Sonnenschein C, Soto AM, et al:: Comparison of short-term estrogenicity tests for identification of hormone-disrupting chemicals. Environ Health Perspect 1999, 107(Suppl 1):89-108.

32. Payne J, Jones C, Lakhani S, Kortenkamp A: Improving the reproducibility of the MCF-7 cell proliferation assay for the detection of xenoestrogens. Sci Total Environ 2000, 248:51-62.

33. Rasmussen TH, Nielsen F, Andersen HR, Nielsen JB, Weihe P, Grandjean P: Assessment of xenoestrogenic exposure by a biomarker approach: application of the E-Screen bioassay to determine estrogenic response of serum extracts. Environ Health 2003, 2:12. 
34. Sohoni $P$, Sumpter JP: Several environmental oestrogens are also anti-androgens. J Endocrinol 1998, 158:327-339.

35. Zwijsen RM, Klompmaker R, Wientjens EB, Kristel PM, van der BB, Michalides RJ: Cyclin D1 triggers autonomous growth of breast cancer cells by governing cell cycle exit. Mol Cell Biol 1996, 16:2554-2560.

36. Lukas J, Bartkova J, Bartek J: Convergence of mitogenic signalling cascades from diverse classes of receptors at the cyclin D-cyclin-dependent kinase-pRb-controlled G1 checkpoint. Mol Cell Biol 1996, 16:6917-6925.

37. Wang TC, Cardiff RD, Zukerberg L, Lees E, Arnold A, Schmidt EV: Mammary hyperplasia and carcinoma in MMTV-cyclin D1 transgenic mice. Nature 1994, 369:669-671.

38. Zhang SY, Caamano J, Cooper F, Guo X, Klein-Szanto AJ: Immunohistochemistry of cyclin D1 in human breast cancer. $A m \mathrm{~J}$ Clin Pathol 1994, 102:695-698.

39. Bartkova J, Lukas J, Muller H, Lutzhoft D, Strauss M, Bartek J: Cyclin D1 protein expression and function in human breast cancer. Int J Cancer 1994, 57:353-361.

40. Planas-Silva MD, Shang Y, Donaher JL, Brown M, Weinberg RA: AIB1 enhances estrogen-dependent induction of cyclin D1 expression. Cancer Res 2001, 61:3858-3862.

41. Cicatiello L, Addeo R, Sasso A, Altucci L, Petrizzi VB, Borgo R, Cancemi M, Caporali S, Caristi S, Scafoglio C, Teti D, Bresciani F, Perillo B, Weisz A: Estrogens and progesterone promote persistent CCND1 gene activation during G1 by inducing transcriptional derepression via c-Jun/c-Fos/estrogen receptor (progesterone receptor) complex assembly to a distal regulatory element and recruitment of cyclin D1 to its own gene promoter. Mol Cell Biol 2004, 24:7260-7274.

42. Eeckhoute J, Carroll JS, Geistlinger TR, Torres-Arzayus MI, Brown $\mathrm{M}$ : A cell-type-specific transcriptional network required for estrogen regulation of cyclin D1 and cell cycle progression in breast cancer. Genes Dev 2006, 20:2513-2526.

43. Poulin R, Simard J, Labrie C, Petitclerc L, Dumont M, Lagace L, Labrie F: Down-regulation of estrogen receptors by androgens in the ZR-75-1 human breast cancer cell line. Endocrinology 1989, 125:392-399.

44. Valley CC, Métivier R, Solodin NM, Fowler AM, Mashek MT, Hill L, Alarid ET: Differential regulation of estrogen-inducible proteolysis and transcription by the estrogen receptor alpha $\mathrm{N}$ terminus. Mol Cell Biol 2005, 25:5417-5428.

45. Fan M, Nakshatri H, Nephew KP: Inhibiting proteasomal proteolysis sustains estrogen receptor-alpha activation. Mol Endocrinol 2004, 18:2603-2615.

46. Petrel TA, Brueggemeier RW: Increased proteasome-dependent degradation of estrogen receptor-alpha by TGF-beta1 in breast cancer cell lines. J Cell Biochem 2003, 88:181-190.

47. Lonard DM, Nawaz Z, Smith CL, O'Malley BW: The 265 proteasome is required for estrogen receptor-alpha and coactivator turnover and for efficient estrogen receptor-alpha transactivation. Mol Cell 2000, 5:939-948.

48. Wormke M, Stoner M, Saville B, Safe S: Crosstalk between estrogen receptor alpha and the aryl hydrocarbon receptor in breast cancer cells involves unidirectional activation of proteasomes. FEBS Lett 2000, 478:109-112.

49. Nawaz Z, Lonard DM, Dennis AP, Smith CL, O'Malley BW: Proteasome-dependent degradation of the human estrogen receptor. Proc Natl Acad Sci USA 1999, 96:1858-1862.

50. Alarid ET, Bakopoulos N, Solodin N: Proteasome-mediated proteolysis of estrogen receptor: a novel component in autologous down-regulation. Mol Endocrinol 1999, 13:1522-1534.

51. Andò S, De Amicis F, Rago V, Carpino A, Maggiolini M, Panno ML, Lanzino M: Breast cancer: from estrogen to androgen receptor. Mol Cell Endocrinol 2002, 193:121-128.

52. Lanzino M, De Amicis F, McPhaul MJ, Marsico S, Panno ML, Andò $S$ : Endogenous coactivator ARA70 interacts with estrogen receptor alpha (ERalpha) and modulates the functional ERalpha/androgen receptor interplay in MCF-7 cells. J Biol Chem 2005, 280:20421-20430.

53. Yeh S, Chang C: Cloning and characterization of a specific coactivator, ARA70, for the androgen receptor in human prostate cells. Proc Natl Acad Sci USA 1996, 93:5517-5521.

54. Shoker BS, Jarvis C, Sibson DR, Walker C, Sloane JP: Oestrogen receptor expression in the normal and pre-cancerous breast. J Pathol 1999, 188:237-244.
55. Clarke RB: Human breast cell proliferation and its relationship to steroid receptor expression. Climacteric 2004, 7:129-137.

56. Birrell SN, Butler LM, Harris JM, Buchanan G, Tilley WD: Disruption of androgen receptor signaling by synthetic progestins may increase risk of developing breast cancer. FASEB J 2007, 21:2285-2293.

57. Prest SJ, May FE, Westley BR: The estrogen-regulated protein TFF1, stimulates migration of human breast cancer cells. FASEB J 2002, 16:592-594.

58. Luqmani YA, Campbell T, Soomro S, Shousha S, Rio MC, Coombes RC: Immunohistochemical localisation of pS2 protein in ductal carcinoma in situ and benign lesions of the breast. Br J Cancer 1993, 67:749-753.

59. Lackey BR, Gray SL, Henricks DM: Crosstalk and considerations in endocrine disruptor research. Med Hypotheses 2001 56:644-647. 